\title{
ANALISIS POLIMORFISME NUKLEOTIDA TUNGGAL (SNP) DAERAH 3'UTR GEN LDLR PENDUDUK PAPUA
}

\author{
Asri Saffanah Pratiwi ${ }^{*}$, Achmad Taher ${ }^{1}$ \\ ${ }^{1}$ Jurusan Kimia FMIPA Universitas Papua \\ Jl. Gunung Salju Amban, Manokwari, 98314, Papua Barat \\ E-mail: pasri_saffanah@yahoo.co.id
}

\begin{abstract}
ABSTRAK
Keragaman suku di Papua yang tinggi berpotensi menghasilkan keragaman genetik, salah satunya pada gen $L D L R$. Gen $L D L R$ adalah gen penyandi protein reseptor LDL yang berfungsi mengatur kadar kolesterol dalam darah. Gen $L D L R$ tersusun dari 18 ekson serta mengandung daerah 3'UTR. Daerah 3'UTR berperan penting dalam pengaturan ekpresi gen. Penelitian ini bertujuan melihat potensi keragaman genetik penduduk Papua yang berasal dari suku suku yang berbeda berdasarkan daerah 3'UTR gen $L D L R$. Penelitian dilakukan dengan metode reaksi berantai polimerase untuk melipatgandakan jumlah DNA target, kemudian disekuensing untuk mengetahui urutan basa nukleotida. Hasil penelitian ini menunjukkan dari 6 mahasiswa Universitas Papua (UNIPA) asal Papua yang dijadikan sampel, ditemukan 2 SNP pada posisi $* 52$ dan *504 dengan keragaman nukleotida $(\pi)$ sebesar 0,00149 . Polimorfisme ini membentuk 3 jenis haplotipe, yaitu GG, GA dan AA dengan nilai keragaman haplotipe $0,600 \pm 0,215$.
\end{abstract}

Kata kunci : 3’UTR, gen $L D L R$, penduduk Papua, SNP

\begin{abstract}
Single nucleotide polymorphism (SNP) is a single nucleotide difference in the arrangement of DNA base strands that can show genetic variation. The LDLR gene is a low density lipoprotein (LDL-R) receptor gene that functions to regulate cholesterol levels in the blood. The LDLR gene is composed of 18 exons and contains a 3'untranslated region (3'UTR) which plays an important role in regulating gene expression. This study aims to analyze the SNP in an area of 3'UTR LDLR genes from 6 University of Papua students from Papua. The research was carried out by polymerase chain reaction method to multiply the number of target DNA, then sequenced to find out the sequence of nucleotide bases. The results of this study were from 6 individuals, found 2 SNPs at position *52 and *504 with nucleotide diversity $(\pi)$ of 0.00149 . These polymorphisms forms 3 types of haplotypes, namely GG, GA and $A A$ with a haplotype diversity of $0.600 \pm 0.215$.
\end{abstract}

Keyword : 3'UTR, LDLR gene, Papuan, SNP

\section{PENDAHULUAN}

Papua memiliki banyak suku dengan ciri khasnya masing-masing. Keragaman suku yang tinggi ini berpotensi menghasilkan keragaman genetik salah satunya pada gen reseptor lipoprotein densitas rendah (Low-Density Lipoprotein Receptor, LDLR). Gen LDLR adalah 
gen pengkode protein reseptor lipoprotein densitas rendah (LDL-R) yang memediasi endositosis partikel LDL sehingga memainkan peranan penting dalam mengontrol kadar kolesterol dalam plasma manusia dan hewan (Francke et al., 1984). Gen $L D L R$ terletak pada kromosom 19 pada pita 19p13.2. Gen ini memiliki panjang lebih dari 45 kilobasa $(\mathrm{kb})$ dan terdiri dari 18 ekson, 17 intron, serta mengandung daerah 3' untranslated region (UTR) dan 5'UTR (Südhof et al., 1985).

Daerah 3'UTR terletak di hilir dari urutan pengkodean protein. Daerah ini berperan dalam berbagai proses pengaturan termasuk pembelahan transkrip, stabilitas dan poliadenilasi, terjemahan dan lokalisasi mRNA. Daerah ini sangat penting dalam menentukan nasib mRNA. Daerah 3'UTR merupakan daerah yang paling panjang dari suatu rantai mRNA (Barrett et al., 2013). Daerah 3'UTR gen LDLR memiliki panjang sekitar 2,5 kb (Südhof et al., 1985).

Daerah 3'UTR telah banyak dipelajari variasi genetiknya melalui analisis keberadaan polimorfisme nukleotida tunggal (Single Nucleotide Polymorphism, SNP). Fagundes et al. (2005) meneliti 111 orang yang berasal dari Afrika, Asia, Kaukasia dan Amerika menemukan 21 SNP pada daerah 3'UTR gen LDLR. Chen et al. (2008) menganalisis 197 orang Cina menemukan adanya 6 SNP. Werutsky (2006) meneliti karakterisasi molekul gen $L D L R$ pada 40 pasien FH di Rio Grande do Sul, Brasil, menemukan adanya 3 SNP pada daerah 3'UTR. Khusus untuk penduduk Papua, keberadaan SNP pada daerah 3'UTR telah dilaporkan oleh Munir (2018). Hasil penelitian tersebut, yang mengambil sampel 9 orang mahasiswa Universitas Papua (UNIPA) asal Papua, menemukan adanya 2 SNP pada daerah 3'UTR.

Penelitian ini merupakan kelanjutan dari penelitian Munir (2018), yaitu dengan menambah jumlah sampel mahasiswa yang dianalisis SNP-nya pada daerah 3'UTR gen LDLR. Sampel yang ditambahkan berasal dari kabupaten yang sama maupun dari kabupaten yang berbeda dari sampel yang diteliti oleh Munir (2018). Tujuannya untuk melihat potensi keragaman genetik penduduk Papua yang berasal dari suku suku yang berbeda.

\section{METODE PENELITIAN}

\section{Sampel Darah}

Sampel darah diperoleh dari 6 mahasiswa aktif UNIPA yang berasal dari suku berbeda menggunakan metode selective purposing, yaitu 1 orang Aruisai, 2 orang Nduga, 1 orang Onate dan 2 orang Byak. Mahasiswa yang darahnya dijadikan sebagai sampel terlebih dahulu diberi penjelasan mengenai tujuan pengambilan 
darahnya dan diminta kesediaannya secara sukarela untuk berpartisipasi dalam

\section{Pengambilan Darah}

Sampel darah diambil dari vena tangan sebanyak $1 \mathrm{~mL}$ menggunakan alat suntik. Sampel darah kemudian dimasukkan dalam tabung vakum yang berisi antikoagulan EDTA.

\section{Ekstraksi dan Amplifikasi DNA}

DNA genomik diekstraksi menggunakan Genomic DNA Mini Kit (Tissue) mengikuti prosedur yang diberikan oleh perusahaan Geneaid, Taiwan. Amplifikasi daerah 3'UTR gen LDLR dilakukan menggunakan metode PCR. Pasangan primer yang digunakan merujuk pada penelitian sebelumnya (Taher et al., 2016). Primer forward yang digunakan adalah $\mathrm{F}$ : 5'GAGGGATCAGGATGTGGGAG-3'

sedangkan primer reverse yang digunakan adalah

$\mathrm{R}: \quad 5$ '-

\section{ACCACGGATTCAGCCAGATC-3'}

dengan ukuran hasil amplifikasi 713 pb.

Komponen campuran master mix untuk PCR sebanyak $25 \mu \mathrm{L}$ terdiri dari $1 \mu \mathrm{L}$ primer UTR forward $10 \mathrm{pmol}, 1 \mu \mathrm{L}$ primer UTR reverse 10 pmol, 12,5 $\mu \mathrm{L}$ Gotaq Green, 5,5 $\mu \mathrm{L}$ Nuclease Free Water dan 5 $\mu \mathrm{L}$ cetakan DNA.

PCR terdiri dari denaturasi awal pada suhu $94^{\circ} \mathrm{C}$ selama 3 menit lalu tahapan 40 siklus. Setiap siklus dilakukan penelitian ini.

dengan tahapan reaksi sebagai berikut: sampel didenaturasi pada suhu $94^{\circ} \mathrm{C}$ selama 30 detik, dilanjutkan annealing pada suhu $50^{\circ} \mathrm{C}$ selama 30 detik, dan extension pada suhu $72^{\circ} \mathrm{C}$ selama 3 menit. Setelah itu dilanjutkan dengan post extension pada suhu $72^{\circ} \mathrm{C}$ selama 5 menit, dan diakhiri pada suhu $25^{\circ} \mathrm{C}$ selama 2 menit.

\section{Elektroforesis Gel Agarosa}

Produk PCR dideteksi menggunakan elektroforesis gel agarosa $1,8 \%$ dan sebagai penanda digunakan $1 k b \quad D N A$ Ladder. Hasil elektroforesis diamati menggunakan alat GelDoc dan dibaca hasilnya di komputer dengan aplikasi Quantity One. Keberadaan produk PCR ditunjukkan dengan adanya pita (band) dalam gel hasil elektroforesis.

\section{Sekuensing Amplikon}

Produk hasil purifikasi selanjutnya dikirim ke First Base Laboratory Sdh Bhd (Malaysia) untuk dianalisis sekuennya menggunakan dideoxy sequencing in $A B I$ 3730XL automated DNA sequencer.

\section{Analisis Data}

Sekuen forward dan reverse yang diperoleh dianalisis menggunakan program Mega 7.0 untuk mendapatkan sekuen konsensus. Sekuen konsensus selanjutnya 
disejajarkan dengan sekuen rujukan di GenBank (nomor akses FJ525879.1) dengan Basic Local Search Alignment Tools (BLAST). Pensejajaran sekuen, analisis perbedaan nukleotida, keragaman nukleotida $(\pi)$, jarak genetik dan pohon filogenetik dilakukan menggunakan program Mega 7.0 (Kumar et al., 2016). Pensejajaran menggunakan Clustal W, jumlah perbedaan nukleotida menggunakan opsi number of differences, perhitungan jarak genetik berdasarkan Kimura 2-parameter dan pohon filogenetik dibentuk berdasarkan neighbor-joining dengan melakukan bootstraps sebanyak 1000 pengulangan. Analisis haplotipe dilakukan menggunakan program DnaSP 6.11 (Rozas et al., 2017). Analisis medianjoining network dilakukan menggunakan program Network 5.0 (Bandelt et al., 1999).

\section{HASIL DAN PEMBAHASAN}

Amplifikasi dan Sekuensing Daerah 3'UTR

Daerah 3'UTR gen $L D L R$ dari 6 sampel berhasil diamplifikasi menggunakan primer forward dan reverse. Produk amplifikasi yang diperoleh sebesar 713 pb. Pita DNA hasil amplifikasi dapat dilihat pada Gambar 1.

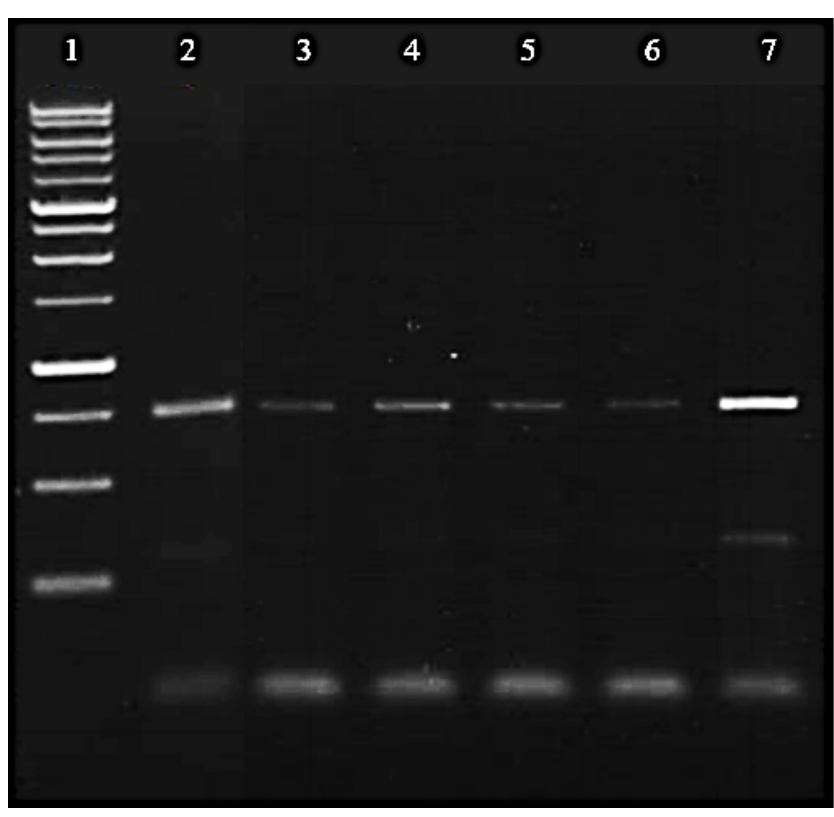

Gambar 1. Pita DNA produk PCR. Keterangan (1) $1 \mathrm{~kb} \quad \mathrm{DNA}$ Ladder, (2) Aruisai, (3) Nduga1, (4) Onate, (5) Nduga-2, (6) Byak-1, (7) Byak-2

Produk amplifikasi kemudian disekuensing dan diperoleh hasilnya dalam bentuk elektroforegram berupa puncak dari urutan basa nukleotida (Gambar 2). Setiap basa nukleotida memberikan warna puncak yang berbeda, yaitu Adenin berwarna hijau, Guanin berwarna hitam, Timin berwarna merah dan Sitosin berwarna biru. Hasil pensejajaran sekuen konsensus dengan sekuen rujukan di GenBank (kode akses FJ525879.1) menunjukkan sekuen terdiri atas $94 \mathrm{pb}$ yang merupakan bagian 17 intron, $36 \mathrm{pb}$ merupakan bagian ekson 18, dan 583 pb merupakan bagian 3'UTR. 


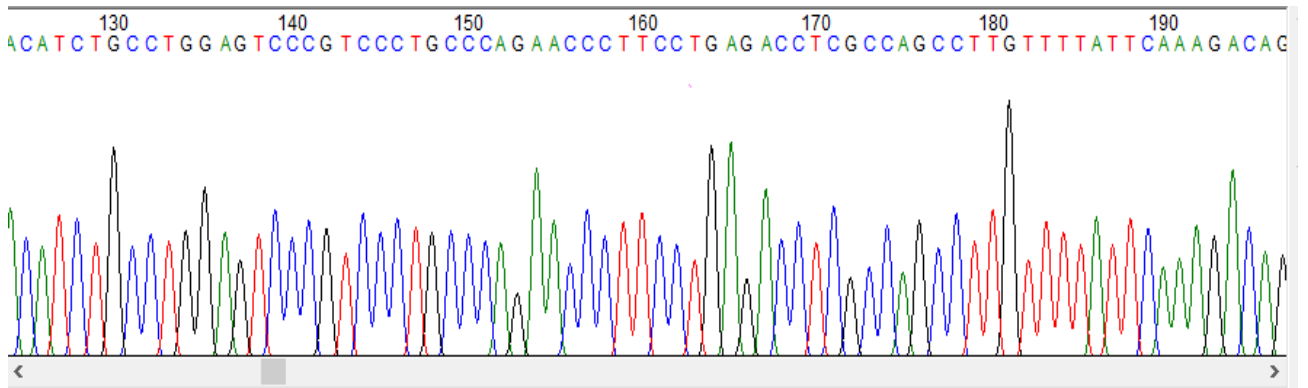

Gambar 2. Fragmen elektroferogram sampel Byak-2

Variasi Nukleotida antar Sekuen 3'UTR

Gen $L D L R$

Analisis variasi nukleotida dari sekuen 3'UTR berdasarkan perbedaan komposisi nukleotida diperoleh jumlah perbedaan antar pasangan sekuen. Jumlah perbedaan nukleotida berkisar antara 0 sampai 2 nukleotida dengan rataan sebesar 0,867 nukleotida dan keragaman nukleotida $(\pi)$ sebesar 0,00149. Jumlah perbedaan paling jauh ditunjukkan oleh sekuen asal Byak-2 dengan Nduga-1, Onate, Nduga-2 dan Byak-1. Sekuen dengan jumlah perbedaan 1 nukleotida ditunjukkan oleh individu asal Aruisai dengan kelima individu lainnya. Sedangkan perbedaan nukleotida 0 menunjukkan bahwa setiap sekuen individu yang diperoleh memiliki kesamaan atau identik. Matriks perbedaan nukleotida antar pasangan sekuen dapat dilihat pada Tabel 1.
Berdasarkan perbedaan nukleotida dapat diketahui jarak genetik antar pasangan sekuen. Jarak genetik yang diperoleh berkisar antara $0,000(0,0 \%)$ hingga 0,003 (0,3\%) Individu asal Nduga1, Onate, Nduga-2 dan Byak-1 memiliki jarak genetik yang dekat, yaitu sebesar $0,000 \quad(0,0 \%)$. Individu asal Aruisai menunjukkan jarak genetik 0,002 (0,2\%). Sedangkan jarak genetik terbesar, yaitu $0,003(0,3 \%)$ ditunjukkan oleh individu asal Byak-2 dengan individu asal Nduga-1, Onate, Nduga-2 dan Byak-1. Tingginya nilai jarak genetik menujukkan semakin jauh hubungan kekerabatannya. Sebaliknya, nilai jarak genetik yang rendah menujukkan hubungan kekerabatan yang semakin dekat. Jarak genetik antar pasangan sekuen ditampilkan pada Tabel 2.

Tabel 1. Matriks perbedaan nukleotida antar pasangan sekuen

\begin{tabular}{cccccccc}
\hline No. & ID Sampel & 1 & 2 & 3 & 4 & 5 & 6 \\
\hline 1. & Aruisai & & & & & & \\
2. & Nduga-1 & 1 & & & & & \\
3. & Onate & 1 & 0 & & & & \\
4. & Nduga-2 & 1 & 0 & 0 & &
\end{tabular}




\begin{tabular}{lllllll}
5. & Byak-1 & 1 & 0 & 0 & 0 & \\
6. & Byak-2 & 1 & 2 & 2 & 2 & 2 \\
\hline
\end{tabular}

Tabel 2.Jarak genetik antar pasangan sekuen

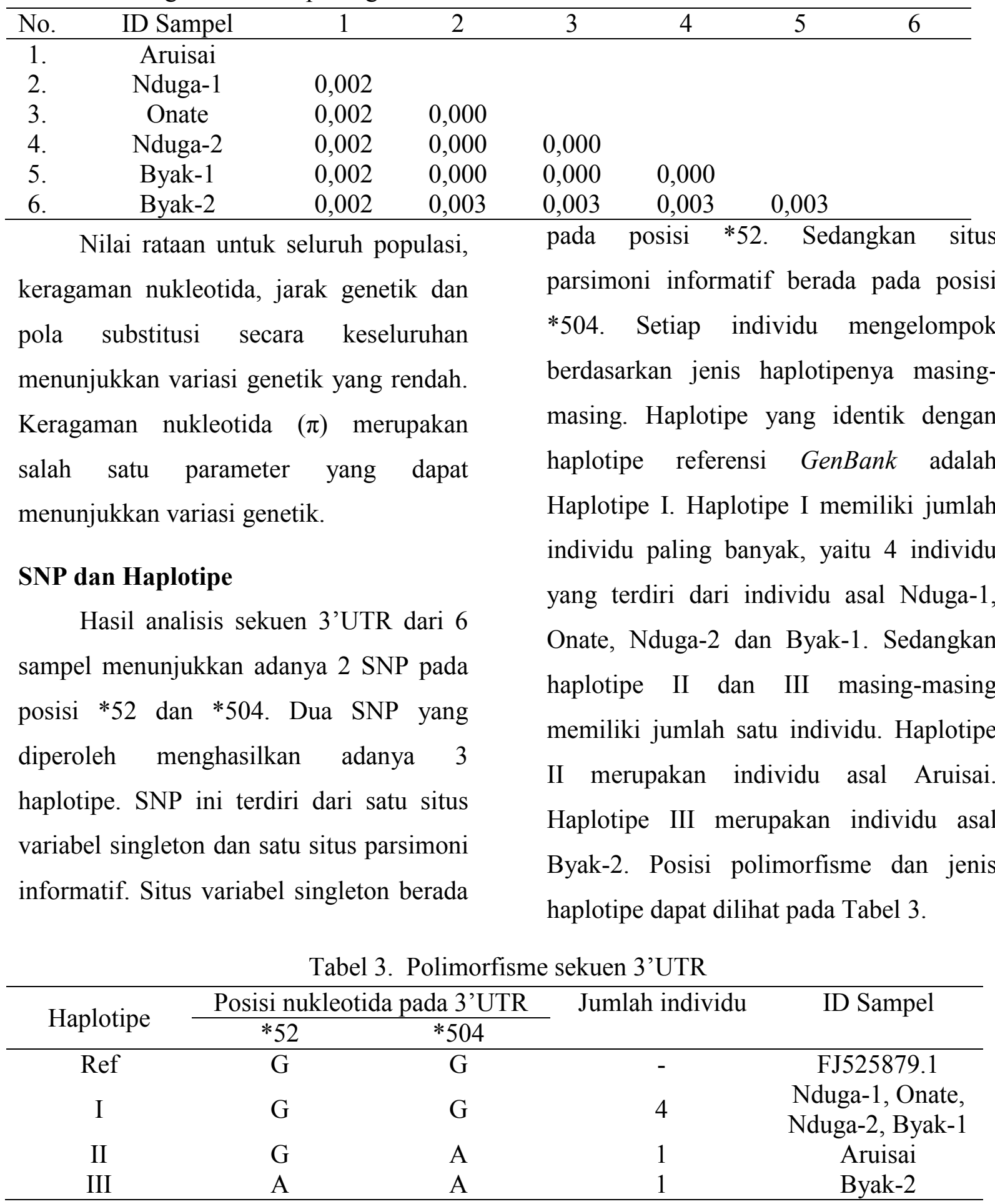




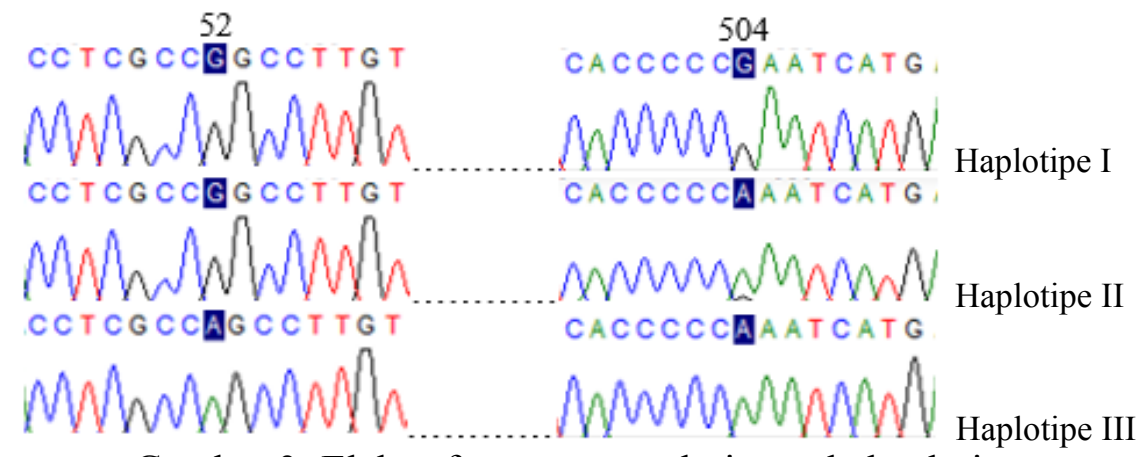

Gambar 3. Elektroferogram untuk tiga pola haplotipe

menandakan tingkat keragaman genetik

Haplotipe yang dihasilkan dapat digolongkan menjadi haplotipe umum dan haplotipe khusus. Haplotipe I (GG) dan haplotipe II (GA) tergolong haplotipe umum karena dimiliki oleh lebih dari satu individu. Haplotipe III (AA) tergolong haplotipe khusus karena hanya dimiliki oleh satu individu. Nilai keragaman haplotipe yang diperoleh sebesar 0,600 \pm 0,215. Keragaman haplotipe dapat menunjukkan tingkat keragaman genetik. Haplotipe yang semakin beragam semakin tinggi.

Berdasarkan keragaman haplotipe tersebut, dapat dibuat pohon filogenetik. Keenam sampel pada pohon filogenetik mengelompok berdasarkan haplotipenya. Nduga-2, Byak-1, Onate dan Nduga-1 mengelompok dan berada pada posisi paling jauh dari Byak-2. Sedangkan Aruisai berada di antara kedua haplotipe. Pohon filogenetik untuk keenam sampel ditampilkan pada Gambar 4.

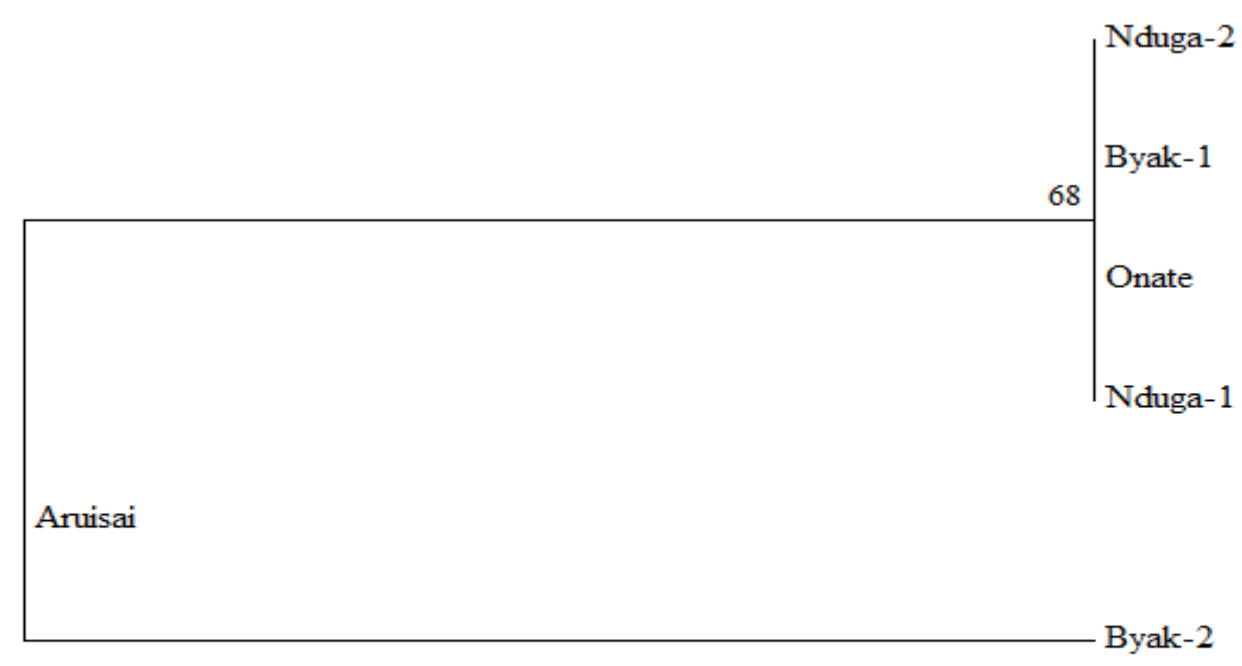

$\stackrel{\vdash}{0.00020}$

Gambar 4. Pohon filogenetik berdasarkan sekuen 3'UTR 
Haplotipe I merupakan haplotipe umum untuk seluruh haplotipe yang teridentifikasi. Haplotipe I dan haplotipe II berbeda 1 nukleotida pada posisi $* 504$. Haplotipe II dan haplotipe III menunjukkan perbedaan 1 nukleotida pada posisi *52. Sedangkan haplotipe I dan haplotipe III memiliki perbedaan 2 nukleotida pada posisi $* 52$ dan $* 504$. Hasil analisis median-joining network dari polimorfisme sekuen 3'UTR dapat dilihat pada Gambar 5.

Sekuen asal Byak merupakan sekuen yang paling beragam. Hal ini dikarenakan sekuen tersebut terbagi dalam dua haplotipe, yaitu haplotipe I dan haplotipe III. Walaupun individu Byak-1 dan Byak-2 berasal dari suku yang sama, dapat dilihat bahwa mereka dapat menghasilkan polimorfisme.

Perbandingan dengan Penelitian Sebelumnya

Penelitian sebelumnya untuk melihat keragaman genetik daerah 3'UTR gen
LDLR dari 9 mahasiswa UNIPA telah dilakukan oleh Munir (2018). Pada dasarnya, hasil yang diperoleh pada penelitian ini hampir sama dengan hasil dari penelitian sebelumnya.

Jumlah SNP yang diperoleh pada penelitain ini sama banyak dengan penelitian sebelumnya yaitu 2 SNP. Namun terdapat perbedaan pada posisi SNP. Titik SNP yang diperoleh oleh penelitian sebelumnya adalah pada posisi *315 dan *504. Penelitian ini juga menemukan titik SNP pada posisi $* 504$, serta mendapatkan titik SNP yang baru, yaitu pada posisi *52. Perubahan nukleotida pada posisi *315 yang ditemukan sebelumnyaadalah $\mathrm{C}>\mathrm{G}$. Pada posisi $* 504$, kedua penelitian sama-sama menemukan perubahan nukleotida $\mathrm{G}>\mathrm{A}$. Perubahan nukleotida pada posisi $* 52$ yang ditemukan pada penelitian ini adalah $\mathrm{G}>$ A. Penemuan titik SNP yang baru ini dapat menambahkan polimorfime pada daerah 3'UTR gen LDLR mahasiswa UNIPA.

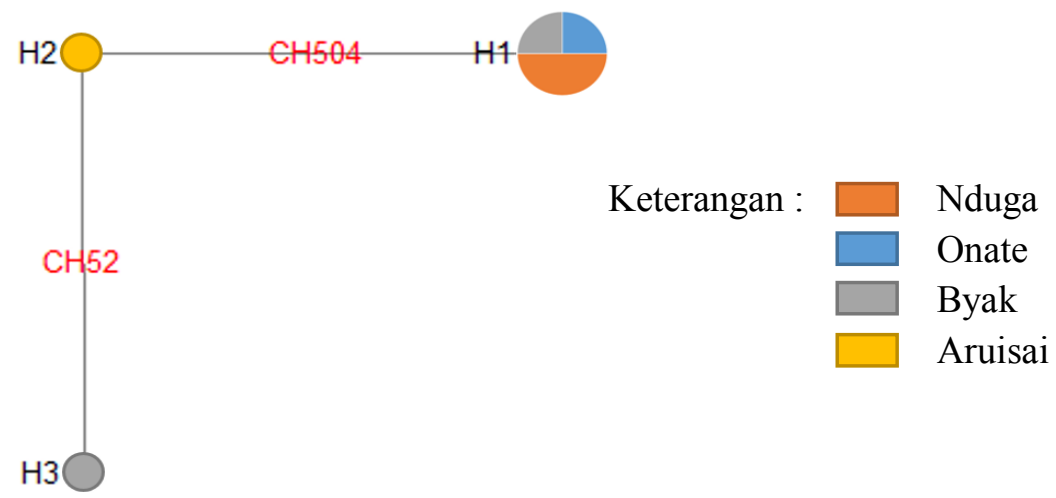

Gambar 5. Median-joining network polimorfisme sekuen 3'UTR 
Posisi SNP yang berbeda menyebabkan haplotipe yang diperoleh juga berbeda. Haplotipe pada penelitian Munir adalah CG, GG dan CA. Sedangkan pada penelitian ini diperoleh haplotipe GG, GA dan AA. Nilai keragaman haplotipe dari kedua penelitian tidak berbeda jauh. Pada penelitian Munir (2018), diperoleh keragaman haplotipe $0,556 \pm 0,165$. Pada penelitian ini diperoleh keragaman haplotipe 0,600 \pm 0,215 .

\section{KESIMPULAN}

Hasil penelitian ini menunjukkan adanya 2 SNP pada posisi $* 52$ dan $* 504$ dengan keragaman nukleotida $(\pi)$ sebesar 0,00149. Kedua SNP yang diperoleh membentuk 3 jenis haplotipe, yaitu GG, GA dan AA dengan nilai keragaman haplotipe $0,600 \pm 0,215$.

\section{DAFTAR PUSTAKA}

Bandelt, H. J., Forster, P., Röhl, A. 1999. Median-Joining Networks for Inferring Intraspecific Phylogenies. Molecular Biology and Evolution, 16(1), 37-48

Barrett, L. W., Fletcher, S., Wilton S. D. 2013. Untranslated Gene Regions and Other Non-coding Elements: Regulation of Eukaryotic Gene Expression. Springer Science \& Business Media. Australia
Chen, W., Wang, S., Ma, Y., Zhou, Y., Liu, H., Strnad, P., Kraemer, F. B., Krauss, R. M., Liu, J. 2008. Analysis of Polymorphisms in The 3'Untranslated Region of The LDL Receptor Gene and Their Effect on Plasma Cholesterol Levels and Drug Response. International Journal of Molecular Medicine, 21(3), 345-353

Fagundes, N. J. R., Salzano, F. M., Batzer, M. A., Deininger, P. L., Bonatto, S. L. 2005. Worldwide Genetic Variation at the 3'UTR Region of the LDLR Gene: Possible Influence of Natural Selection. Annals of Human Genetic, 69(4), 389-400

Francke, U., Brown, M. S., Goldstein, J. L. 1984. Assignment of The Human Gene for The Low Density Lipoprotein Receptor to Chromosome 19: Synteny of A Receptor, A Ligand, and A Genetic Disease. Proceedings of the National Academy of Sciences of the United States of America, 81(9), 2826-2830

Munir, M., Taher, A. 2018. Keragaman Genetik Penduduk Papua: Polimorfime pada Daerah 3'UTR Gen Reseptor Lipoprotein Densitas Rendah (LDLR). Prosiding Seminar Nasional MIPA UNIPA, 3(1), 47-55

Rozas, J., Ferrer-Mata, A., SánchezDelBarrio, J. C., Guirao-Rico, S., Libradi, P., Ramos-Onsins, S. E., Sánchez-Gracia, A. 2017. DnaSP 6: DNA Sequence Polymorphism Analysis of large Data Sets. Molecular Biology and Evolution, 34(12), 3299-3302

Südhof, T. C., Goldstein, J. L., Brown, M. S., Russell, D. W. 1985. The LDL Receptor Gene: A Mosaic of Exon Shared with Different Proteins. Science, 228(4701), 815-822 
Taher, A., Solihin, D. D., Sulistiyani, Sajuthi, D., Astuti, D. A. 2016. Genetic Diversity within the 3'UTR Basic and Applied Research, 26(1), 237248

Werutsky, C. A. 2006. As Bases Moleculares das Hipercolesterolemias Familiares no Brasil o Rio Grande do Sul. Tesis. Universidade de São Paulo of the Cynomolgus Macaque (Macaca Fascicularis) LDLR Gene. International Journal of Science: 